\title{
Composing music, developing dialogues: An enactive perspective on children's collaborative creativity
}

\author{
Ana Luísa Veloso \\ Rua Dr. Roberto Frias, 602 4200-465 Porto Portugal \\ anaveloso@ese.ipp.pt
}

This study aims to provide new insights on the nature of the embodied and collaborative processes related to the emergence of new musical ideas that occur when children are composing in groups.

Data was obtained by participant observation of the teacher/researcher and by ten videotaped one-hour musical sessions dedicated to the development of a music composition by two groups of children, all of whom were eight years old.

It was found that when composing in groups a) children use embodied processes to transform what they experience on diverse realms of their existence into musical ideas, and that b) while creating music, children engage in several improvisatory moments where new ideas emerge through the diverse ways they enact the surroundings where the activity is occurring. Findings suggest a conception of music composing as a multidimensional phenomenon that entails cognitive processes that are distributed across and beyond the physical body. Findings also suggest that composing music in collaboration with others nurtures a set of creative possibilities that would otherwise, not occur. Considerations for music education theory and practice are addressed in the last section of the article.

\section{Introduction}

In the last two decades, the concepts of embodied and distributed cognition, in conjunction with new research frames drawn from sociocultural theories, have brought about new insights into the nature and the processes involved in musical creativity, and thus fostering new questions and challenges for music education practice and research. This perspective was developed though a paradigmatic change against the prevalent cognitivist and representationalist position developed during the 1960s and 1970s (Bruner, 1990) and that was then reconceptualized in the field of Music Cognition and Music Psychology. Based on the assumption of a dualistic separation between the body and the mind of individuals and also between the individuals and the world that surrounds them, this particular view emphasizes that cognitive processes are wrapped inside the brain that acts as an information-processing centre, defining human behaviour through the information that is sent to the body. This view led researchers in the field of music cognition and psychology to conceptualize processes such as motor skills and mental states as eminently separated, and as distinct moments of all musical experience (Sloboda, 2005; Lehmann, Sloboda \& Woody, 2007). As Lehmann, Sloboda and Woody (2007) explain:

[M]usic making is not primarily a physical but a mental skill, in which the hands, fingers, breathing apparatus, and so forth, merely follow directions from higher 
levels. Skilled music listening is a solely mental activity. We therefore propose that the common mechanisms that mediate the execution of skills are internal mental representations and auxiliary processes that act on those representations (p. 19).

The concept of embodiment, on the other hand, proposes that our intellectual constructs are rooted in cognitive schemata that trace their origins to the body. Consequently, all our knowledge and abstract thought emerges from our situated embodied experiences. Drawing on this perspective, some researchers (inter alia Bowman, 2000, 2004; Bowman \& Powell, 2007; Krueger, 2009) have increasingly closed off the scope for music cognition being purely abstract and related to a disembodied brain, and instead focus on contextualized musical practices as the basis for reconstructing concepts such as mind, creativity, emotion or learning. Furthermore, since cognitive processes are rooted in the body and in the ways the body/mind unity relates to other persons and to the surrounding world, this new shift in music cognition research requires studies targeting human action and interaction, and the ways in which human beings create new musical meanings from the relationships they establish with sound and others (Bowman, 2000, 2004; Johnson, 2007). Following these ideas, such studies on educational contexts approaching musical creativity are now challenged to reach beyond the examination of individual creative mental activities and extend their analysis to the dynamic and interactive processes emerging out of children's collaborative creativity (Faulkner, 2003; MacDonald, Miell \& Morgan, 2000; Sawyer, 2003, 2006, 2012; Sawyer \& DeZutter, 2009; Veloso \& Carvalho, 2012).

\section{The enactive approach to embodiment and distributed cognition}

The various themes and theoretical positions advocated in this study are centred on a particular embodiment perspective of cognition that Varela, Thompson and Rosch (1993) entitled the 'enactive approach' (p. 173). This conception underlies the proposal that cognition grows from the sensorimotor dynamics that emerge during the interactions established between living organisms and their environment; therefore cognition is a form of action - action embodied and contextualized by the particular setting where such occurs (Thompson, 2005, 2007; Stewart, Gapenne \& Di Paolo, 2010).

Within the context of this theoretical framework, the term 'embodied' itself contains two essential points. The first defines how cognition depends on the experiences deriving from the fact that we have bodies deploying various sensorimotor capacities. The second states that these sensorimotor capacities are themselves immersed in a biological, psychological and cultural context. Closely linked with this concept, the word 'action' seeks to emphasize how our sensitive and motor processes, as well as perception and action, represent inseparable constituents of our experiences and therefore also of our cognition (Bowman, 2000, 2004; Bowman \& Powell, 2007; Varela et al., 1993). According to these authors, reality is not something external to us, merely reflected and represented in our minds, but rather an actively constructed phenomenon, enacted by human beings through their constant interactions with the world.

Hence, we may correspondingly state that mind and body form an inseparable continuum, which is simultaneously situated in a particular social context. Thus, the body does not get separated from the mind, and mind/body unity emerges through our 
experience in the world. Dealing with musical events therefore constitutes an experience that reaches beyond a fragmentary pursuit. Indeed, this amounts to a global experience involving mind, body and context. Endorsing the main ideas of the enactive approach to embodiment, several researchers (Bowman, 2000, 2004; Johnson, 2007; Krueger, 2009; Schiavio \& Cummins, 2015; Schiavio \& Høffding, 2015) are provoking deep and wide reaching reflection on the meanings, values and practices developed in music education and emphasizing how our motor, sensory and conceptual processes have all evolved in conjunction, sharing basic neurological mechanisms that prove inseparable in the development of musical practices and knowledge.

From this perspective two notions extremely important to our understanding of music cognition arise: the first one is that cognition is a distributed process, and the mind a distributed entity, that lives, on the one hand, 'in the vast network of neural interconnections that extend throughout the body' (Bowman, 2004, p. 36), and, on the other hand, beyond the physical body, into the cultural and social realms of our lives (Bowman, 2000, 2004; Johnson, 2007; Sawyer \& DeZutter, 2009; Schiavio \& Høffding, 2015; Zbikowski, 2002).

This theoretical lens resonates deeply with the work of scholars such as Vygotsky (1978), who developed a sociocultural approach to human cognition and knowledge. According to the sociocultural approach, cognition is a result of a constant interplay between the individual and the surrounding context, and is defined through the processes of participation and negotiation that human beings established within culturally constructed symbol systems. This lens also resonates with the views of 'situated learning' explored by Lave (1988) and Lave and Wenger (1991), which state that learning occurs in social interactions and is 'distributed - stretched over, not divided among - mind, activity and culturally organized settings' $(1988$, p. 1). In respect of education, Salomon acknowledges that 'the product of the intellectual partnership that results from the distribution of cognitions across individuals or between individuals and cultural artefacts is a joint one; it cannot be attributed solely to one or another partner' (1997, p. 112).

Summarizing these understandings into the field of Music Cognition, and also acknowledging recent perspectives developed in the field of Cognitive Sciences and Philosophy of Mind (Johnson, 2007; Thompson, 2005, 2007), Schiavio and Høffding (2015) clarified that:

the kind of interaction occurring among participants in a musical event is enabled by cognitive processes that are distributed across the whole body of each subject and the environment, and thus are not reducible to structures 'in the head'. In an intersubjective musical context, therefore, sense-making is participatory because it is not dependent on individual mental processes of meaning attribution, but is obtained through the dynamical interplay of bodies in action (p. 6).

The second issue is the concept of cross-modal transfer (Bowman, 2004; Johnson, 2007). Cross-modal transfer is rooted in the theoretical construct that musical thinking is grounded in other fields of experience that serve as structural and organizational models for the development of musical knowledge. As Bowman (2000) explains:

$[\mathrm{M}]$ ind and its all workings are inextricably linked to and fundamentally relied upon bodily roots. The most supremely intellectual achievements, then, are rooted in 
cognitive schemata which are of corporeal origin. Cognition, on this view, consists in acts of metaphorically extending, projecting, or mapping bodily-derived schemata on to other realms. And importantly, this act of metaphorical projection works crossmodally, synesthetically (p.9).

The examples enclosed in this definition are numerous, either developed through bodily experiences - the musical texture is dense or empty, the time slow or fast, whether we are in or out of tune or the sounds are bright, sharp, dry or dark - or emanating from our sociocultural experiences - sounds and musical blocks also become violent, funny or melancholic.

In conclusion, what seems crucial in the definition of these concepts is that children, when interacting musically, apply the embodied schemes and cultural metaphors acquired in other dimensions of their lived experience. Thus, the boundaries between sound, self and others gradually fade and these three entities together create, from the children's respective particular musical experiences, multiple paths of knowing and becoming (Finnegan, 2003).

\section{Understanding Children's group composing through Collaborative Creativity}

In this article, composition in groups is studied through the notion of 'collaborative creativity', a perspective that considers creativity as a property distributed by the group (Sawyer, 2006, 2012; Sawyer \& DeZutter, 2009) and the creative outcomes emerging from children's musical actions as unpredictable and contingent to moment to moment interactions among the group's members. Revisiting authors such as Vygotsky (1978) or Bruner (1990, 1996), researchers in the field of collaborative creativity sustain the view that 'creativity is social in nature and located in the space "in between" self and others' (Glaveanu, 2011, p. 9). This perspective runs against the sociocognitive approach to 'group creativity', that considers the 'social' as an external factor that influences the process.

In the last decades, group creativity (the term used by sociocognitivists) has been mainly studied through the sociocognitive perspective. The sociocultural approach (and its related concept of collaborative creativity) is still at a young age, and although there is already some literature published in the field (John-Steiner, 2000; Miell, Littleton \& Rojas-Drummond, 2008; Miell \& Littleton, 2004; Sawyer, 2003, 2006, 2012; Sawyer \& DeZutter, 2009), as Miell, Littleton and Rojas-Drummond (2008) remind us, in one of the most compelling advancements in the field of collaborative creativity and music education ${ }^{1}$, there is still a significant need for further research in diverse social settings where collaborative creativity might take place. Indeed, more recently, Barrett (2014) has also asserted that 'creative thought and practice that is collective and collaborative has only recently become the focus of research and provides further opportunity to trouble the 'creative imaginary' of creative thought and practice in music' (p. 8). In a chapter entitled 'Communication, collaboration and creativity: How musicians negotiate a collective "sound", Littleton and Mercer (2012) also draw our attention to the fact that 'more needs to be understood about the interactional processes of creative collaboration, in music and other spheres of activity' (p. 240). Following the claims advanced by these scholars, the present paper will analyse the musical interactions that take place between children, their colleagues and the specific 
artefacts and tools they are using while creating a musical piece together, taking in account that in order to clarify the processes involved in musical creative collaborations and its implications to music education, we need to go beyond verbal communication, researching also 'the ways that other non-verbal means and cultural tools (including playing music) are used to constitute and sustain such activity' (idem, p. 235).

As this study was developed in a school context with children, the concept of creativity is built under the umbrella of what Kaufman and Beghetto (2009) named 'mini c creativity', a concept also used by Craft et al (2013), in the study of 'Possibility Thinking' in the classroom and the ways it evolves among children. 'Mini c creativity' is defined as as 'novel and personally meaningful interpretation of experiences, actions, and events', that help us to 'bring a level of specificity necessary to ensure that the creative potential of children is nurtured (rather than overlooked)' (Kaufman \& Beghetto, 2009, pp. 3-4). Within this framework, music composition in children's contexts is interpreted as 'a culturally mediated form of meaning-making ( . . ) most effectively described as a dialogue between the child as musician and composer, the emerging musical work, the culture that has produced the composer and the emerging work, and the immediate setting in which the transaction takes place' (Barrett, 2003, p. 6). Such a definition acknowledges those musical and artistic experiences lived by children in informal contexts such as family or friends, opening the creative process to children's contributions, whether at the level of musical instruments and sound objects, musical ideas, ideas to the structure of a possible final performance, or of ways of interacting with their colleagues. It is, therefore, a definition that fully considers children's social and cultural contexts, and the necessity they feel to establish connections between their experiences inside and outside school. And as a matter of fact, the more classroom projects acknowledge what children experience outside school, the more truthful and meaningful they will be (Gromko, 2003; Barrett, 2011). It is also a definition that emphasises a truly important principle in education: the one of creating meaning to the world, to better understand our selves in cooperation with others (Allsup, 2011; Loveless, 2007).

Following the definition proposed by Barrett (2003) music composition in the present article is examined as a broad concept, centered on the creative process and integrating improvisation, here conceived as a 'a form of creativity that is spontaneous, and based on process rather than product, social rather than individual and a universal capacity, latent or otherwise' (MacDonald, Wilson \& Miell, 2012, p. 242). This perspective resonates with the concept of 'musical invention', (MacDonald, Byrne \& Carlton, 2006; Hargreaves, MacDonald \& Miell, 2012), a term that tries to move beyond the apparent dichotomies that exist in creative modes of musical action such as composition, improvisation, or arrangement, and is understood as the "creation of music that is new to the originator and that has come about through a process of experimentation, trial and error, sharing of musical ideas, collaborative work and that may or may not be written down in some form or other' (MacDonald, Byrne \& Carlton, 2006, p. 293). This conceptualization is an attempt to overtake divergences in what differentiates music composition and improvisation, recognizing the interdependence that often exists between the two. The creation of new music, as any form of human of agency, is, as has been seen above, fully, eminently social, and dependent on the context, and on the specific ways human beings interact with each other and with the tools and artefacts available to them (e.g. musical instruments, sound 
Table 1. Music education in compulsory education in Portugal

\begin{tabular}{lllll}
\hline \hline $\begin{array}{l}\text { Number of } \\
\text { academic } \\
\text { years } \\
\text { age }\end{array}$ & Pupils, & $\begin{array}{l}\text { Music education } \\
\text { as a curricular } \\
\text { subject }\end{array}$ & $\begin{array}{l}\text { Professional } \\
\text { responsibility for } \\
\text { teaching music } \\
\text { education }\end{array}$ \\
\hline $\begin{array}{l}\mathbf{1}^{\text {st }} \text { cycle } \\
\mathbf{2}^{\text {nd }} \text { cycle }\end{array}$ & 4 & $6-9$ & Compulsory & $\begin{array}{l}\text { Primary school teacher } \\
\mathbf{3}^{\text {rd }} \text { cycle }\end{array}$ \\
\hline \hline
\end{tabular}

objects, computers and other forms of digital technology). Therefore, it seems imprudent to envisage definitions of music composition and music improvisation independently of the specificities of the context where the music is being created. Thus, throughout the paper the main focus will be on the ways children bring new musical ideas into being when they are interacting with their colleagues and the specific tools available to them.

\section{Music Education in Portuguese Primary Schools}

In Portugal, compulsory education is divided into three learning cycles. As shown in Table 1, music education is a compulsory subject only in the first and second cycle (Ministério da Educação, 2007).

The present research was developed in a public primary school ( $1^{\text {st }}$ cycle of Education). In Primary schools there is one class teacher that is responsible for teaching all curriculum areas, including the arts. Guided by the general program for primary education, the classroom teacher is responsible to nurture the development of the essential skills and knowledge of each subject matter, in a gradual manner.

Arts are an essential part of the curriculum and so it is expected that the primary school teacher might also teach music. However, in most cases primary school teachers do not feel confident enough about their music skills to develop a music syllabus in the classroom. Therefore, quite often music is absent from classroom activities and its provision during curriculum time depends solely on the particular primary school teacher in charge.

\section{Research context}

The data reported in this study is part of the final project conducted within a broader longitudinal study, aimed at fostering new understandings of the ways music composition activities in small and large groups might promote the development of musical thinking among children. This longitudinal study was developed in an action research design with me acting as a teacher/researcher. This methodology was used in order to promote, in the specific context of a music classroom, a transformative pathway in children's lives (Bowman, 2009; Elliott, 2004). The goal was to foster new opportunities for children to grow as musicians, individual and social beings, through their creative engagement with music. For this purpose, action research was used as means to attain a deeper understanding of the processes occurring in the music classroom, and to reflect on new and better ways 
Table 2. Projects and Activities from January 2008 to June 2010

\begin{tabular}{|c|c|c|}
\hline Period & Projects and activities & Results \\
\hline $\begin{array}{l}\text { January } 2008 \\
\text { to June } 2009\end{array}$ & $\begin{array}{l}\text { Creative work with sound } \\
\text { material }\end{array}$ & $\begin{array}{l}\text { Exploration and Experimentation with } \\
\text { sound materials and objects. } \\
\text { Improvisatory group games. }\end{array}$ \\
\hline $\begin{array}{r}\text { October } 2009 \\
\text { to June } 2010\end{array}$ & Project "Magic Sounds" & $\begin{array}{l}\text { Small and large group composing from } \\
\text { an illustrated book. Concert with the presentation } \\
\text { of musical pieces. }\end{array}$ \\
\hline $\begin{array}{l}\text { January } 2011 \\
\text { to June } 2011\end{array}$ & Project "Train of secrets" & $\begin{array}{l}\text { Large group composing from the idea of } \\
\text { a voyage to an imaginary country. } \\
\text { Concert with the presentation of } \\
\text { musical pieces. }\end{array}$ \\
\hline
\end{tabular}

to proceed. In essence, this methodology allows music teachers to look at themselves as teachers/researchers, collecting and analysing data in a participative and reflective way, searching not for an objective truth but rather for the construction of multiple realities, recognizing each unique pupils' perceptions and perspectives and the surrounding context that influences these perspectives (Bowman, 2009; Carr, 2006; Elliott, 2004).

The fieldwork for the present research project took place between January 2011 and June 2011, during ten sessions of one hour each, in a Portuguese public primary school with 72 children belonging to the three third-grade classes. None of these 72 children, all aged around eight years old, had had any contact with formal music education. However, they had already been introduced to improvisation and composition activities as part of the aforementioned longitudinal study, from January 2008 to June 2010. Therefore, when the present project began, they had already participated, for a year and a half, in creative activities and in a project of group composing (Table 2).

This creative musical work developed previously during the longitudinal study and documented in other settings (Veloso, 2012; Veloso \& Carvalho, 2012), endowed children with several tools and the knowledge for growing further in this latest project. Furthermore it also helped me to know better all the students, in musical and non-musical terms. As a matter of fact, and as already mentioned in the literature review, the entire process occurred acknowledging the cultural background of children, as this was considered as a decisive element to involve children in what was being proposed to them. Everything was planned and executed in a constant dialogue with children that continuously gave several ideas to the development of the projects and activities, defining also many elements and structural points of these same projects and activities in musical and other than musical terms.

Project implementation was previously discussed and agreed upon with the school director, the primary teachers and the parents, who all signed an agreement providing their consent to the audio and video recording of all sessions and their subsequent usage for research purposes. There was also agreement that none of these children would have music education classes in any other formal setting, and that each class would be divided in half and the real names of the children participating in the project would not be revealed; therefore, the children's names were all correspondingly altered. 


\section{Describing the process-The 'Train of Secrets'}

The project idea was introduced through an informal dialogue with children and inviting them to imagine a world they would like to visit and the train journey to that chosen world. The final goal was to create and perform a musical piece inspired by the most meaningful events that had occurred during each individual journey. The project name came about during those moments in which the children were sharing with their peers and myself what they had seen, heard or felt during their voyage. All the pupils accepted the challenge with great joy, and, therefore, in the next sessions, each child embarked on his/her imaginary voyage, which developed through the following stages:

1. Imagining a voyage to a chosen world. For this purpose, the children sat or lay down on the floor, closing their eyes while listening to Trem do Caipira composed by Heitor Villa Lobos. I chose Trem do Caipira for this moment because this musical piece recreates a train journey to an unknown place in Brazil. My goal was for the children, by listening to the music, to feel, through the embodiment of the musical movements, rhythms and dynamics, as if they were travelling inside the train and towards a world they had previously chosen.

2. In an informal group conversation proposed by me, each child revealed to their peers and myself the name of the world they had chosen and what they had seen, heard or felt during the journey.

3. Together, the pupils then created visual representations of their journeys on small coloured papers: the children wrote what they felt on red paper; what they heard on yellow paper and what they saw on blue paper. These small papers were attached to a long paperboard according to the point in the journey when they had occurred. This became their visual score for the music composition process. In addition to the coloured papers, pupils added drawings, words and symbols to the score.

4. Thus, the children collaboratively created a music composition. While the visual score served as a guide, many other ideas emerged when each group was jointly composing. The first musical ideas were created during reflexive dialogues on the visual score in which I acted as mediator. The children were sat in the middle of the classroom to form a U shape. Together, we reviewed the visual score and divided it into sections. Then, for each respective section, we discussed how we could transform the visual content into sound. In these moments, children usually felt an urgent need to try the conventional and non-conventional musical instruments placed in the classroom, and also applying their voices to this end. This would therefore lead to moments of sound exploration and, many times, large moments of improvisation. Then they would discuss further about what they had done, choosing or rejecting an option, focusing on and developing an idea that one of them had created. When happy with the music they had created, they would then rehearse it. These processes occurred alternatively and over several cycles until the music composition was finished.

Phase four represents the main source of the data analysed and interpreted in this paper.

5. In June, all participants prepared and performed their original compositions in a school concert. 


\section{Data collection}

The data presented in this article emerges from two groups of 12 children of two different classes. As mentioned previously, during the project I worked with 72 students, belonging to three different classes of 24 students each. For the purpose of this study, each class was divided in half, each group had 12 students. Space does not allow me to describe here the work developed by the six groups of children. The two groups analysed in the findings section (named here A and B) were chosen accordingly to the richness and diversity of data available.

Data for this study includes field notes, ten videotaped one-hour musical sessions of each one of the groups, and photographs and artefacts created by children (e.g. the visual scores). The data collection methods stemmed from that which emerged as relevant, and therefore expanding the analysis into a deeper reflection on the most meaningful actions and events. As I was acting as a teacher researcher, the methods were selected within the context of practice, while meaningful circumstances were developed throughout the course of the research project. Thus, at times, there was a real need for students to talk about what they were doing and the meaning they were creating in their work and, to achieve this I introduced moments of dialogue that are recorded in the videos and in my field notes, taken from participant observation. The field notes also allowed me to express my impressions and thoughts on the children's actions and interactions ongoing throughout the process, something I usually did right after the end of each section. (Angrosino, 2008). The video recordings, along with the photographs, provided powerful evidence of the actions, expressions, gestures and dialogue undertaken by participants during the various events and activities.

\section{Data analysis}

This study focuses on the nature of embodied and collaborative processes related to the emergence of new musical ideas that occur when children are composing in groups.

Bearing in mind the complexity of collaborative creativity related phenomena, data from field notes and video recordings were coded according to meaningful units of text, speech and video, detailing the processes by which children went about interrelating their individual musical ideas with those already established by the group. The coded data were then grouped and organized into categories that were later triangulated in the search for relationships within and between them (Denzin, 2001; Saldana, 2009). Codes and categories were not pre-established; rather, they emerged from in depth analysis of field notes and transcripts of all videos, in order to organize and find meaningful patterns related to the overall topics being investigated. Although data from video recordings gave me a more concrete base about children's words and actions, the interpretation that follows is the result of my immersion on the data, and therefore of my particular position as a teacher and researcher. In doing this I follow Talburt who states that:

rather than searching for the triangular point at which three lines meet, and thus creating an interpretation that represents a seemingly coherent and verifiable world, researchers might look for multiple convergences and divergences in their data - and admit to their own interpretative uncertainty (2004, p. 90). 
Table 3. Metaphorical projection

\begin{tabular}{lll}
\hline \hline $\begin{array}{l}\text { Elements of the } \\
\text { Score }\end{array}$ & $\begin{array}{l}\text { Felt qualities } \\
\text { (Embodiment of } \\
\text { experiential qualities) }\end{array}$ & $\begin{array}{l}\text { Musical ideas (Cross-modal } \\
\text { transfer) }\end{array}$ \\
$\begin{array}{l}\text { Atmosphere of } \\
\text { The seashore }\end{array}$ & Tranquillity Quietness & Soft sounds on the melodica \\
See waves & Movement of the waves & $\begin{array}{l}\text { One strike on the tum drum } \\
\text { Slide on the skin of the drum } \\
\text { Train's Derailment }\end{array}$ \\
\hline \hline
\end{tabular}

After this process, photographs and the artefacts made by children were used to corroborate or alienate the ideas that were emerging. Within the context of this study, triangulation serves as 'a strategy for validating results and procedures then an alternative to validation, which increases the scope, depth, and consistency in methodological procedures' (Flick, 2002, p. 227).

This process of analysis and interpretation led to two main themes that are then later developed, theorized and extended in the discussion section.

\section{Findings}

This project found that, whenever these two groups of children were creating together, ideas emerged through two different although strictly connected ways:

a) Metaphorical Projection:

- Embodiment of experiential qualities;

- Cross model transfer.

b) Collaborative Enactment:

- Enactment with music;

- Enactment with others.

a) Metaphorical Projection. Examples in this thematic unit included moments devoted to the creation of musical motifs and the structural elements of the piece. Usually, this involved musical interpretations of the visual score that originated novel musical motifs and ideas as well as the development of essential structural characteristics of the piece, such as dynamics, tempo, texture or instrumentation (see Table 3).

In the example that follows, taken from my field notes, pupils from group A are taking their first steps in the compositional process with their first ideas seeming to emerge from the visual score.

Vignette 1

To recreate the atmosphere of the seashore, Gustavo suggests the idea of a piano playing softly. The problem was that our piano was broken and the only thing that 
existed was a melodica. Gustavo agrees to play his idea on it and in the following minutes tries out several motifs and musical lines, some faster, some slower. I realize that Gustavo is totally focused on soft sounds and the ways of playing those sounds. This does not seem an easy task for him but Gustavo doesn't give up on his search. Sarah, on the other hand, plays a percussive motif on a tom drum in order to recreate the sea waves hitting the rocks. She uses two drumsticks to strike once in the tom drum and then continues with a slide on the skin of the drum. Later, she tells me that the strike on the drum 'is the wave hitting on the sand', and the slide 'is when the waves move back'.

This process of relating the visual score to specific musical ideas happened on many occasions as the elaboration of the music composition underwent development. Group B, in its third session, is composing the section Derailment:

\section{Vignette 2}

Students choose an old utensil that has a handgrip that, when moved, makes a rusty, dragged, sound. They also choose two small ratchets that can be played at a faster or slower tempo, depending on the desired effect. At the end of the allegro section, Ana Carolina starts bending the handgrip at a fast tempo that slowly decreases into a quiet movement resembling the train's damage. The rest of the group follow Ana Carolina, playing a long rallentando that moves out into silence.

Our composers/ improvisers/ performers, and now also actors, mimic the train's movement in a sort of collective fading. At the end of the section, I only hear Ana Carolina, the ratchet and some baffled sounds that some pupils were still making with their instruments...

In these moments, pupils seemed to embody the musical characteristics represented in the visual score, transforming pictures, signs and words, into music. According to the reviewed literature, this transformation is strongly mediated by children's bodies, by what they were actually experiencing and feeling at the time they were composing. As observed previously in this article, textures, dynamics or tempo are not abstractions intrinsic to music, but qualities felt and experienced by individuals interacting with sounds, that present 'the flow of human experience, feeling and thinking in concrete and embodied forms' (Johnson, 2007, p. 237). As Bowman suggests:

[E]xperience that is musically profound extends well beyond intramusical attributes like structural complexity, technical refinement, or expressive beauty. What is distinctive about musical profundity is the depth, range, magnitude and range of experiences invoked. Music that is profound taps into and resonates deeply and richly with life experience, living us with a vivid and extraordinary sense of aptness (2004, pp.43, 44).

While composing, each child experienced in her own body-mind the tensions, releases, intensities or textures of the music; the qualities and ambiences children tried to create through musical sounds were projections of what they were actually feeling in their bodies: the tranquillity of the seashore, the flow of the sea waves, the movements of the train, 
Table 4. Collaborative Enactment

\begin{tabular}{lll}
\hline \hline Enaction with Music & Reinforcing ideas & Novel ideas \\
\hline $\begin{array}{l}\text { The music and one } \\
\text { colleague }\end{array}$ & $\begin{array}{l}\text { Sara joins Paulo and } \\
\text { accompanying him on the } \\
\text { tom drum, creating a new } \\
\text { motif and bringing a fresh } \\
\text { movement to the } \\
\text { composition }\end{array}$ & \\
$\begin{array}{l}\text { The music and the } \\
\text { group }\end{array}$ & $\begin{array}{l}\text { Gustavo finds space to make a } \\
\text { solo. He starts by } \\
\text { improvising freely on the } \\
\text { guitar, playing all along the } \\
\text { neck and looking for } \\
\text { different timbres and } \\
\text { approaches to the guitar. }\end{array}$ \\
\hline \hline
\end{tabular}

are examples of that (Bowman, 2000, 2004; Johnson, 2007; Schiavio \& Høffding, 2015; Zbikowski, 2002).

The two vignettes presented here might be considered as windows to further understanding the ways in which cognition is distributed throughout the body, and also the ways in which cross-modality occurs. According to Bowman (2000, 2004) and Johnson (2007) our cognition is rooted in processes of extending and projecting, in a metaphorical way, bodily maps and schemas derived from other fields of experience, in a multi-sensory way. This seems to explain how children transformed visual ideas into music. They did it through the body, through felt movements and sensations evoked by what was described in the visual score: the atmosphere of the seashore was achieved musically through soft sounds in the melodica; the flow of the sea waves first through a glissando on the metalophones, in pianissimo, and then trough a punctuated heat on the drum when the waves hit the rocks; and the movement of the train when it was breaking off, through a rallentando that evokes a slower.... slower. slower tem. po.

In summary, when these two groups of children were composing they were deploying schemes from other experiences informed and enabled by the body, transforming gestures, actions, movements, emotions and ideas into music. Their creative accomplishments were a result of the felt experiences lived by their bodies, that were, at the same time, responses to the affordances of the circumstances, tools and artefacts that shaped the context in which children were composing.

Composing was this global experience. Everything that happened was part and influenced the music they created. And as we will see in the last section of the article, this might have significant consequences to the field of music education and to the ways teachers think about music composition, and musical learning in general.

B) Collaborative Enactment. As observed in Table 4, this theme embraces moments of deep engagement with others and the musical material. 
These were occasions characterized by intense musical and emotional flows, where the body, the mind, and the music lived in a strong and mutual enaction. In such circumstances, music seemed to guide the situation. Children seemed conducted by an emotional pathway, defined by the embodiment of the musical dialogues that are occurring. Their breathing, their gestures, their movements became smooth with the sound, with its textures, its dynamics and shapes in such a way that children seemed to be feeling 'a willingness to be open to what is being defined, and to let it control the situation' (Allsup, 2011, p. 29). The truth is that I applied this same expression while in the process of transcribing and coding the videos and analysing a session with group $\mathrm{A}$ in which pupils were performing the section 'Allegro'

\title{
Vignette 3
}

The group improvises freely and suddenly I realize they are not in control of the music any more. Rather, the music seems to be controlling their steps. In the beginning of the section 'Allegro', Sara joins Paulo and accompanying him on the tom drum, creating a new motif and bringing a fresh movement to the composition.

I'm seated on a chair listening to their music. Gustavo improvises on the melodica, Raquel sets the movement, in a punctuated rhythm, using a slide flute. Another student joins the group, improvising on the glockenspiel. As the music moves around, I hear myself saying:

Ana Luísa: Good! Carry on!

Students continue playing and Teresa joins them, improvising on a bass xylophone.

Ana Luísa: Bravo, bravo! Well done!

These improvisatory moments were constantly occurring during the composition process. They abound in the video recordings and in my field notes. Here is how I described a session when group A was playing the section Happiness:

\begin{abstract}
Vignette 4
Students play and stop as if they are entering and leaving the 'train of secrets'. All of a sudden I hear the soprano xylophone joining the glockenspiel. Beatriz, playing the bass xylophone, takes this cue and joins the group. Later, I join my students, playing tambourine. Sara is using her tom drum as if she was playing with a bass drum and a snare drum: she hits twice in the tom drum's centre and twice on its rim. After a brief moment she changes the rhythm, maintaining the motif on the tom's centre but percussing only once on the trim. The rest of the group follows Sara's new rhythm by striking twice on the wood of their Orff instruments and once on the metal plates or wooden bars. In that moment, everyone is playing the same and Gustavo finds space to make a solo. He starts by improvising freely on the guitar, playing all along the neck and looking for different timbres and approaches to the guitar.
\end{abstract}

In these two examples, children joined the group improvising as they took up the new rhythm, making their own contributions to the overall structure of the performance and also finding spaces to improvise new melodies, as in the case of Gustavo. In the context of this article, this leads us to two major findings:

The first is that, within the context of group composition, improvisation seems to assume a crucial role in the development of the musical piece. As Faulkner observed in a study on group composing: 'Processes seem to start ( . . . ) from individually invented musical ideas, but they are developed, refined and rehearsed through a collective social act of musical agency - group improvisation' (2003, p. 117). Therefore, we might conclude that these two forms of making music are often intertwined and closely related to one 
another. They cohabit and coexist, as two qualitatively different processes, but within the same context of collaborative musical creativity and, hence, two parts of the same unit, informing and transforming each other (Borgo, 2005, Sawyer, 2003).

The second is that during these moments of improvisation, children do not just 'think' in sounds. Rather, they participate with their full bodies, enacting the moment through their interactions with their peers and the music that is been produced in real time. It is therefore important to highlight that these ideas were all created in action, while the music was in motion. As a matter of fact, while improvising, children seem to have entered into the motion of the music 'experiencing all of the ways it moves, swells, hops, rushes, floats, trips along, drags, soars and falls' (Johnson, 2007, p. 239). Children's musical ideas emerged from their enaction with the specific environment in which they were working together, and along with their own playing, the music they were producing affected the entire participation of their colleagues, and therefore, the musical piece that was emerging. In the same way that Schiavio and Høffding (2015) reported that, when studying the performance of a string quartet, a 'sudden rallentando by a member of the quartet will perturb the other subjects' sensorimotor participations, modifying [the goal(s) of] their musical actions' so these students came out with different ideas by enacting the sounds that their colleagues were producing.

Acknowledging creativity as a highly distributed process, we might perhaps say that these overcomes were consequences of pre-reflective, dynamic and embodied responses to what was being played by their colleagues. It was, therefore, a product of the enaction with the sounds, the musical instruments available and each child that was participating in the group. They were the product of collaborative activity, forged in dwelling of the dynamic interactions that occurred.

\section{Breaking walls: Considerations f or Music Education}

Examined through the lenses of the enactive approach to cognition, we may say that children's music composing involves much more than the representation and manipulation of musical images. It goes beyond musical thinking - if understood as a high cognitive feature located inside the brain, as described by the cognitivist approach to music cognition - into a multidimensional and multisensory experience where every single element of the context matters: the organization of space and time, the way the activity or project is presented to children, the musical instruments, sound objects/materials and other tools that are available to them, and most importantly, the ways in which children are invited to participate. Following the findings presented here, it seems clear that music composition activities in the classroom should explicitly account for the ways the body informs and 
enables musical actions. As we distinctly saw in Vignette 1, for example, children's musical ideas were not a merely representation of the sounds of the sea. Rather, they were a presentation, an enactment of the sea movements, colours, and sounds, made possible via the body. Because music cognition is embodied action, it invokes through our bodily roots a wide range of memories, feelings, and thoughts. In this sense, music composition is a means to reflect about life, to create new meanings to our personal and shared worlds, that serves a rather important educational purpose, contributing 'to our sense of self as individuals in relationship with others and the wider world' (Loveless, 2007, p. 6). Therefore it seems crucial that music composition in the classroom might be planned through global projects where music appears in relation to other aspects and experiences of human life and where the boundaries between sound, self and others might be blurred through the mediation of the body, and specifically through metaphorical projection (Bowman, 2000; 2004; Johnson, 2007). Indeed, one of the distinctive characteristics about the data presented in this article is that when these pupils began creating their music, they were not asked to focus their attention on a specific isolated assignment such as 'compose a rhythm piece with four bars'. As children were invited to participate in a project that related the creative act of music making with other experiences of their lives, they felt emotionally involved, which led them to participate in the process of composing with all their energy and enthusiasm, bringing into the classroom memories, thoughts, feelings, dreams, reveries, that then were transformed into music.

Another conclusion that seems of paramount importance for music education, is that when children are collaboratively creating together, they use musical improvisation as a means of communicating with each other in a non-verbal, pre-reflective, dynamic way. During moments of improvisation such as those described in Vignettes 3 and 4, children communicate though musical dialogues. This leads us to a very important conclusion already emphasised by MacDonald, Miell and Morgan (2000): 'that music provides another channel of communication between children besides their talk' that 'can express thoughts, emotions and ideas just as words can' (p. 407), through a dialogue that encompasses sounds, feelings and imagination and that emphasises music as an 'embodied flow of life' (Johnson, 2007, p. 236). Moreover, in terms of musical invention this communication, when occurring during improvisatory moments, leads children to challenge their peers into new possibilities that go along with an increasing growth of musical ideas among the group. When improvising, children rely on each other's clues to invent new musical ideas. As already stated in the findings section, improvisation opens a space to a permanent 'give and take', a musical conversation that affords for creative responses to what each child is playing, and that flows in a social, dynamic, interdependent process. This asks, I believe, for teaching strategies in music education to be less centred on concepts and explanations and more focused on the dynamic aspects of music communication. As observed before, children seem to have the need to experiment - to act, to put their bodies in motion interacting with the tools available - using sounds from their voices and diverse sound objects and musical instruments in order to generate musical ideas. And as described in the findings section, this process leads, many times, to moments of improvisations where these ideas are extended and transformed. Therefore, in the context of this study, it seems rather important that music teachers include collaborative moments of experimentations and improvisation when they are planning music compositions activities in the classroom. 
Thus, in this final section of the article I invite music teachers, when preparing music composition activities to move a little bit away from their reliance on words and verbal explanations about concepts and procedures, and accept the risk of moving into a more uncertain territory, opening spaces where children and teacher explore, improvise, and let ideas emerge through the enaction of sounds, selves and context.

\section{Note}

1 In 2008 the International Journal of Educational Research edited an issue entitled 'Music Education: A site for collaborative creativity'.

\section{References}

ALLSUP, R. E. (2011) Sequoias, mavericks, open doors . . composing Joan Tower. Philosophy of Music Education Review, 19(1), 24-36.

ANGROSINO, M. (2008) Recontextualizing observation: Ethnography, pedagogy, and the prospects for a progressive political agenda. In N. Denzin \& L. Yvona (Eds.), Collecting and interpreting Qualitative Materials (pp. 161-183). Los Angeles: SAGE.

BARRETT, M. (2003) Freedoms and constraints: Constructing musical worlds through the dialogue of composition. In M. Hickey (Ed.), Why and How to Teach Music Composition: A New Horizon for Music Education (pp. 3-30). Reston: MENC.

BARRETT, M. (2011) Towards a cultural psychology of music education. In M. Barrett (Ed.), A Cultural Psychology of Music Education (pp. 1-16). Oxford: Oxford University Press.

BARRETT, M. (2014) Collaborative Creativity and Creative Collaboration: Troubling the Creative Imaginary. Surrey: Ashgate.

BORGO, D. (2005) Sync or Swarm: Improvising Music in a Complex Age. New York: Continuum International Publishing Group.

BOWMAN, W. (2000) A somatic, 'here and now' semantic: Music, body and the self. Bulletin of the Council for Research in Music Education, 144, 45-60.

BOWMAN, W. (2004) Cognition and the body: Perspectives from music education. In L. Bresler (Ed.), Knowing Bodies, Moving Minds: Toward Embodied Teaching and Learning (pp. 29-50). Netherlands: Kluwer Academic Press.

BOWMAN, W. (2009) No one true way: Music education without redemptive truth. In T. Regelski \& J. T. Gates (Eds.), Music Education for Changing Times (pp. 3-15). New York: Springer.

BOWMAN, W. \& Powell, K. (2007) The body in a state of music. In L. Bresler (Ed.), International Handbook of Research in Arts Education (pp. 1087-1106). Dordrecht: Springer.

BRUNER, J. (1990) Acts of Meaning. London: Harvard University Press.

BRUNER, J. (1996) The Culture of Education. Cambridge, MA: Harvard University Press.

CARR, W. (2006) Philosophy, methodology and action research. Journal of Philosophy of Education, 40(4), 421-435.

CRAFT, A., CREMIN, T., BURNARD, P., DRAGOVIC, T. \& CHAPPBELL, K. (2013) Possibility thinking: Culminative studies of an evidence-based concept driving creativity? Education, 41(5), 538-556.

DENZIN, N. K. (2001) Interpretive Interactionism. London: SAGE Publications.

ELLIOTT, J. (2004) The struggle to redefine the relationship between 'knowledge' and 'action' in the academy: some reflections on action research. Educar, 34, 11-26.

FAULKNER, R. (2003) Group composing: pupil perceptions from a social psychological study. Music Education Research, 5(2), 101-124. 
FINNEGAN, R. (2003) Music, experience and the anthropology of emotion. In M. Clayton, T. Herbert, \& R. Middleton (Eds.), The Cultural Study of Music: A Critical Introduction (pp. 181-192). New York: Routledge.

FLICK, U. (2002) An Introduction to Qualitative Research ( $2^{\text {nd }}$ edn.) London: Sage Publications.

FLICK, U. (2014) An Introduction to Qualitative Research. London: SAGE.

GLAVEANU, V. P. (2011) How are we creative together? Comparing sociocognitive and sociocultural answers. Theory \& Psychology, 21(4), 473-492.

GROMKO, J. (2003) Children composing: Inviting the artful narrative. In M. Hickey (Ed.), Why and How to Teach Music Composition: A New Horizon for Music Education (pp. 69-90). Reston: MENC.

HARGREAVES, D., MacDONALD, R. \& MIELL, D. (2012) Explaining musical imaginations: Creativity, performance, and perception. In D. Hargreaves, D. Miell \& R. MacDonald (Eds.), Musical Imaginations: Multidisciplinary Perspectives on Creativity, Performance and Perception (pp. 114). Oxford, UK: Oxford University Press.

JOHNSON, M. (2007) The Meaning of the Body. Chicago: The University Chicago Press.

JOHN-STEINER, V. (2000) Creative Collaboration. Oxford, UK: Oxford University Press.

KAUFMAN, J. C. \& BEGHETTO, R. A. (2009) Beyond big and little: The four c model of creativity. Review of General Psychology, 13(1), 1-12.

KRUEGER, J. (2009) Enacting Musical Experience. Journal of Consciousness Studies, 16(1), 98-123.

LAVE, J. (1988) Cognition in Practice: Mind, Mathematics and Culture in Everyday Life. Cambridge: Cambridge University Press.

LAVE, J. \& WENGER, E. (1991) Situated Learning: Legitimate Peripheral Participation. Cambridge: Cambridge University Press.

LEHMANN, A. C., SLOBODA, J. A. \& WOODY, R. H. (2007) Psychology for Musicians: Understanding and Acquiring the Skills. Oxford, UK: Oxford University Press.

LITTLETON, K. \& MERCER, N. (2012) Communication, collaboration and creativity: how musicians negotiate a collective 'sound'. In D. Hargreaves, D. Miell, \& R. MacDonald (Eds.), Musical Imaginations: Multidisciplinary Perspectives on Creativity, Performance and Perception (pp. 233241). Oxford: Oxford University Press.

LOVELESS, A. (2007) Creativity, Technology and Learning: A Review of Recent Literature (Report 4 update). Bristol: NESTA Futurelab.

MacDONALD, R., BYRNE, C. \& CARLTON, L. (2006) Creativity and flow in musical composition: An empirical investigation. Psychology of Music, 34(3), 292-306.

MacDONALD, R., MIELL, D. \& MORGAN, L. (2000) Social processes and creative collaboration in children. European Journal of Psychology of Education, 15(4), 405-415.

MacDONALD, R., WILSON, G. \& MIELL, D. (2012) Improvisation as a creative process within contemporary music. In D. Hargreaves, D. Miell, \& R. MacDonald (Eds.), Musical Imaginations: Multidisciplinary Perspectives on Creativity, Performance and Perception (pp. 242-258). Oxford: Oxford University Press.

MIELL, D., LITTLETON, K. (2004) Collaborative Creativity: Contemporary Perspectives. London: Free Association Books.

MIELL, D., LITTLETON, K. \& ROJAS-DRUMMOND, S. (2008) Editorial introduction. International Journal of Educational Research, 47(1), 1-2.

MINISTÉRIO DA EDUCAÇÃO (2007) Educação e Formação em Portugal. Retrieved from http://www. dgeec.mec.pt/np4/97/\%7B \$clientServletPath\%7D/?newsId=147\&fileName=educacao_formacao_ portugal.pdf

SALDANA, J. (2009) The Coding Manual for Qualitative Researchers. London, UK: SAGE.

SALOMON, G. (1997) Distributed Cognitions: Psychological and Educational Considerations. Cambridge University Press. 
SAWYER, K. (2003) Group Creativity: Music, Theatre, Collaboration. Mahwah: Lawrence Erlbaum Associates.

SAWYER, R. K. (2006) Explaining Creativity: The Science of Human Innovation. Oxford: Oxford University Press.

SAWYER, K. (2012) Extending sociocultural theory to group creativity. Vocations and Learning, 5(1), 59-75.

SAWYER, K. \& DEZUTTER, S. (2009) Distributed creativity: How collective creations emerge from collaboration. Psychology of Aesthetics, Creativity, and the Arts, 3(2), 81-92.

SCHIAVIO, A. \& CUMMINS, F. (2015) An inter (en) active approach to musical agency and learning. Proceedings of the International Conference on the Multimodal Experience of Music.

SCHIAVIO, A. \& HØFFDING, S. (2015) Playing together without communicating? A pre-reflective and enactive account of joint musical performance. Musicae Scientiae, 19(4), 366-388.

SLOBODA, J. (2005) Exploring the Musical Mind: Cognition, Emotion, Ability, Function. Oxford: Oxford University Press.

STEWART, J., GAPENNE, O. \& DI PAOLO, E. (2010) Introduction. In J. Stewart, O. Gapenne, \& E. Di Paolo (Eds.), Enaction: Toward a New Paradigm for Cognitive Science (pp. vii-xvii). Massachusetts: The MIT Press.

TALBURT, S. (2004) Ethnographic responsibility without the 'real'. The Journal of Higher Education, 75(1), 80-103.

THOMPSON, E. (2005) Sensorimotor subjectivity and the enactive approach to experience. Phenomenology and the Cognitive Sciences, 4(4), 407-427.

THOMPSON, E. (2007) Mind in Life: Biology, Phenomenology, and the Sciences of Mind. Harvard: Harvard University Press.

VARELA, F. J., THOMPSON, E. \& ROSCH, E. (1993) The Embodied Mind: Cognitive Science and Human Experience. Cambridge, MA: MIT Press.

VELOSO, A. L. \& CARVALHO, S. (2012) Music composition as a way of learning: emotions and the situated self. In O. Odena (Ed.), Musical Creativity: Insights from Music Education Research: Insights from Music Education Research. Surrey: Ashgate Publishing, Ltd.

VELOSO, A. L. (2012) Voar Até ao Comboio dos Segredos: A Construção de Significados Partilhados no Desenvolvimento do Pensamento Musical em Crianças do $1^{\circ}$ Ciclo do EB. (Doctoral thesis).

VYGOTSKY, L. S. (1978) Mind in Society. Harvard: Harvard University Press.

ZBIKOWSKI, L. M. (2002) Conceptualizing Music: Cognitive Structure, Theory, and Analysis. New York: Oxford University Press.

Ana Luísa Veloso is a postdoctoral fellow at CIPEM / INET-md - Center for Research in Music Psychology and Music Education, Politécnico do Porto a pole of the Institute of Ethnomusicology - Center for Studies in Music and Dance. She holds a PhD in Music in the field of Education from the University of Aveiro.

She has been developing several projects in the fields of music and education, specifically in the areas of creativity, music composition, improvisation, music in nonformal contexts, music and personal and social transformation; she has also participated in several national and international conferences. She is the Portuguese national coordinator of the European Association for Music in Schools, member of the board of directors of the Portuguese Association of Music Education and director of the Portuguese Journal of Music Education. She actively pursues her activity as a musician and guitar player, collaborating in several groups related to improvisation, contemporary and experimental and sound art. 